\title{
Characteristics of Trace Elements in Volcanic ash of Kelud Eruption in East Java, Indonesia
}

\author{
Diah Dwiana Lestiani ${ }^{1,{ }^{*}, \text { Revi Apryani }}{ }^{2}$, Linda Lestari ${ }^{2}$, \\ Muhayatun Santoso', Eko Prabowo Hadisantoso², and Syukria Kurniawati ${ }^{1}$ \\ ${ }^{1}$ Center for Applied Nuclear Science and Technology, National Nuclear Energy Agency, \\ J. Tamansari 71, Bandung 40132, Indonesia \\ ${ }^{2}$ Faculty of Natural Sciences and Mathematics, National Islamic University of Sunan Gunung Djati, \\ Jl. AH Nasution 105, Bandung 40614, Indonesia
}

Received July 24, 2017; Accepted February 5, 2018

\begin{abstract}
The eruption of Mount Kelud that occurred on February 13, 2014, ejected a huge plume of ash and sand exceeding $26 \mathrm{~km}$ into the air which moved west over the island. The elements content in volcanic ash is important information for further study such as the possibility to utilize the ash. In this study, the volcanic ashes collected from four affected areas in Java were analyzed using neutron activation analysis (NAA) with HPGe detector and X-ray fluorescence. Method validation was applied using the standard reference material SRM NIST 2711a Montana Soil with recovery and accuracy in a good agreement for all elements. The analysis results of volcanic ashes showed a wide range of elements, major elements $\mathrm{Al}, \mathrm{Ca}, \mathrm{Fe}, \mathrm{K}, \mathrm{Mg}, \mathrm{Mn}, \mathrm{Na}$, Si and Ti, trace elements $\mathrm{As}, \mathrm{Cd}, \mathrm{Cu}, \mathrm{Co}, \mathrm{Cr}, \mathrm{V}$, $\mathrm{Zn}, \mathrm{Hf}$, Th and $\mathrm{U}$, and rare earth elements were identified. The results showed heavy metals $\mathrm{As}, \mathrm{Cd}, \mathrm{Cu}, \mathrm{Co}, \mathrm{Cr}$, and $\mathrm{Pb}$ were ranged 3.23-4.42, 17.63-24.09, 49.26-77.10, 10.86-16.03, 11.19-17.79 and 31.4-42.7 $\mathrm{mg} / \mathrm{kg}$, respectively, while rare earth elements such as Ce, Eu, La, and Sm were 9.84-18.43, 0.73-1.02, 2.25-5.66 and $1.34-2.63 \mathrm{mg} / \mathrm{kg}$ respectively. Comparison with other volcanic ashes from Indonesia such as Merapi and Sinabung and world volcanic ashes were applied. The results of the characteristic of elements in Kelud volcanic ash would be valuable information as reference data for their potential utilization.
\end{abstract}

Keywords: neutron activation analysis; X-ray fluorescence; volcanic ash; Kelud Volcano

\section{ABSTRAK}

Letusan Gunung Kelud pada 13 Februari 2014, mengeluarkan banyak abu vulkanik dan pasir yang menghambur dengan jarak melebihi $26 \mathrm{~km}$ ke udara dan tertiup angin ke arah barat pulau Jawa. Abu vulkanik yang disemburkan dari erupsi gunung berapi mengandung berbagai unsur di dalamnya. Kandungan unsur dalam abu vulkanik merupakan informasi penting untuk studi lebih lanjut seperti potensi pemanfaatannya. Dalam penelitian ini, abu vulkanik yang dikumpulkan dari empat daerah yang terkena dampak di Jawa, dianalisis dengan menggunakan analisis aktivasi neutron ( $A A N)$ dengan detektor HPGe dan fluoresensi sinar- $X$. Metode validasi dilakukan menggunakan bahan referensi standar SRM NIST 2711a Montana Soil, dimana hasil analisis didapatkan recovery dan akurasi untuk semua unsur memiliki kesesuaian yang baik dengan nilai sertifikat. Hasil analisis abu vulkanik menunjukkan teridentifikasinya berbagai unsur, dengan unsur mayor $\mathrm{Al}, \mathrm{Ca}, \mathrm{Fe}, \mathrm{K}, \mathrm{Mg}, \mathrm{Mn}, \mathrm{Na}$, Si dan Ti, unsur trace As, Cd, Cu, Co, Cr, V, Zn, Hf, Th dan U, dan tanah jarang. Hasil penelitian menunjukkan logam berat As, Cd, $\mathrm{Cu}$, Co, Cr dan Pb masing-masing berkisar 3,23-4,42; 17,63-24,09; 49,26-77,10; 10,86-16,03; 11,19-17,79 dan 31,4-42,7 mg/kg, sedangkan unsur tanah jarang seperti Ce, Eu, La dan Sm masing-masing adalah 9,84-18,43; 0,73-1,02; 2,25-5,66 dan 1,34-2,63 mg/kg. Dilakukan perbandingan dengan abu vulkanik lainnya dari Indonesia seperti Merapi dan Sinabung, dan abu vulkanik lainnya di dunia. Hasil karakteristik unsur abu vulkanik Kelud akan menjadi informasi yang berharga sebagai data referensi untuk pemanfaatan abu vulkanik.

Kata Kunci: analisis aktivasi neutron; fluoresensi sinar X; abu vulkanik; Gunung Kelud

\section{INTRODUCTION}

Kelud volcano is an active and relatively small stratovolcano located in East Java, Indonesia
(7055'48"S, $112^{\circ} 18^{\prime} 29^{\prime \prime} \mathrm{E}$ and $1731 \mathrm{~m}$ summit elevation). Kelud is known for large explosive eruptions throughout its history. Several major eruptions have occurred in 1901, 1919, 1951, 1966, and 1990. All

* Corresponding author.

Email address : diahdwi@batan.go.id

DOI: 10.22146/ijc.26876

Diah Dwiana Lestiani et al. 
these recent eruptions were very similar and were characterized by a very short duration a few hours but violent with pyroclastic flows and lahars [1-2]. It last erupted on February 13, 2014, destroying the lava dome and a rapidly rising portion ejected a huge plume of ash and sand exceeding $26 \mathrm{~km}$ into the air [2-3]. Over the first few days, the eruption affected more than 200 thousands of people from 35 villages from surrounding districts Blitar, Kediri and Malang [2]. Because of a large quantity of volcanic ash, the eruption could have had effects and reached over long distance area. One of the most affected areas was Yogyakarta which is located more than $275 \mathrm{~km}$ away from Kelud volcano. The ash from this volcano also caused an ash rain in Bandung which is located $667 \mathrm{~km}$ west from Kelud volcano.

The characteristic of trace elements in the ash can provide valuable information related geochemistry of volcanic ash, and the release of toxic elements into the environment that may impact the ecosystem and health. Some elements create more fertile soil and give benefit in agriculture, while other trace elements could be potentially toxic and have negative effects on the ecosystem [4]. Volcano eruption is capable of causing significant environmental repercussions, affecting simultaneously many cycles in the earth's system, impacting on water, soil, and sediments [5]. Besides that, human and animal health effects of volcanic ash, linked to respiratory illness, is closely associated with particle size, which is especially anticipated for diameters $10 \mu \mathrm{m}$ [6], because aerodynamically fine particles successfully negotiate the curves of the throat and are carried to the lungs. Therefore, the assessment of the hazardous content of volcanic ash is important.

The objective of this research was to characterize the trace elements in volcanic ash from Kelud eruption using neutron activation analysis (NAA) and X-ray fluorescence (XRF). The analysis of Indonesian volcanic ashes from Mt Sinabung, Mt Talang and Merapi have been published elsewhere [5,7-8], but the Kelud volcanic ash was published after 1990 Kelud eruption [9]. Neutron Activation Analysis (NAA) is a sensitive analytical technique which useful for performing both qualitative and quantitative multi-element analysis of major, minor, and trace elements in samples from almost every field of scientific or technical interest. It is one of the most mature analytical methods currently used and yet remains highly competitive with others in term of accuracy, detection limits and multi elemental capabilities [10-11]. XRF is a non-destructive method which requires little or no sample preparation and gives reliable results in a reasonable amount of time (few minutes depending on the sample type) [12-13]. XRF is an analytical method to determine the chemical composition of all kinds of materials, in the form of solid, liquid, powder, filtered or others. Compared to some competitive techniques such as AAS and ICPS, XRF has the advantage of generally being nondestructive, multi elemental, fast and economical. It also provides a fairly uniform detection limit across a large portion of the periodic table and is applicable to wide range of concentrations from a $100 \%$ to few parts per million [14]. In the last few years, application of compact bench top MiniPal energy dispersive x-ray spectrometers has increased significantly.

\section{EXPERIMENTAL SECTION}

\section{Samples Collection}

The samples of ash were collected in 4 cities in Java: Kediri (one day after the eruption), Yogyakarta, Kebumen and Bandung (two days after the eruption). These sites were located on the west side from Kelud. The sampling sites were shown in Fig. 1. Kediri is located

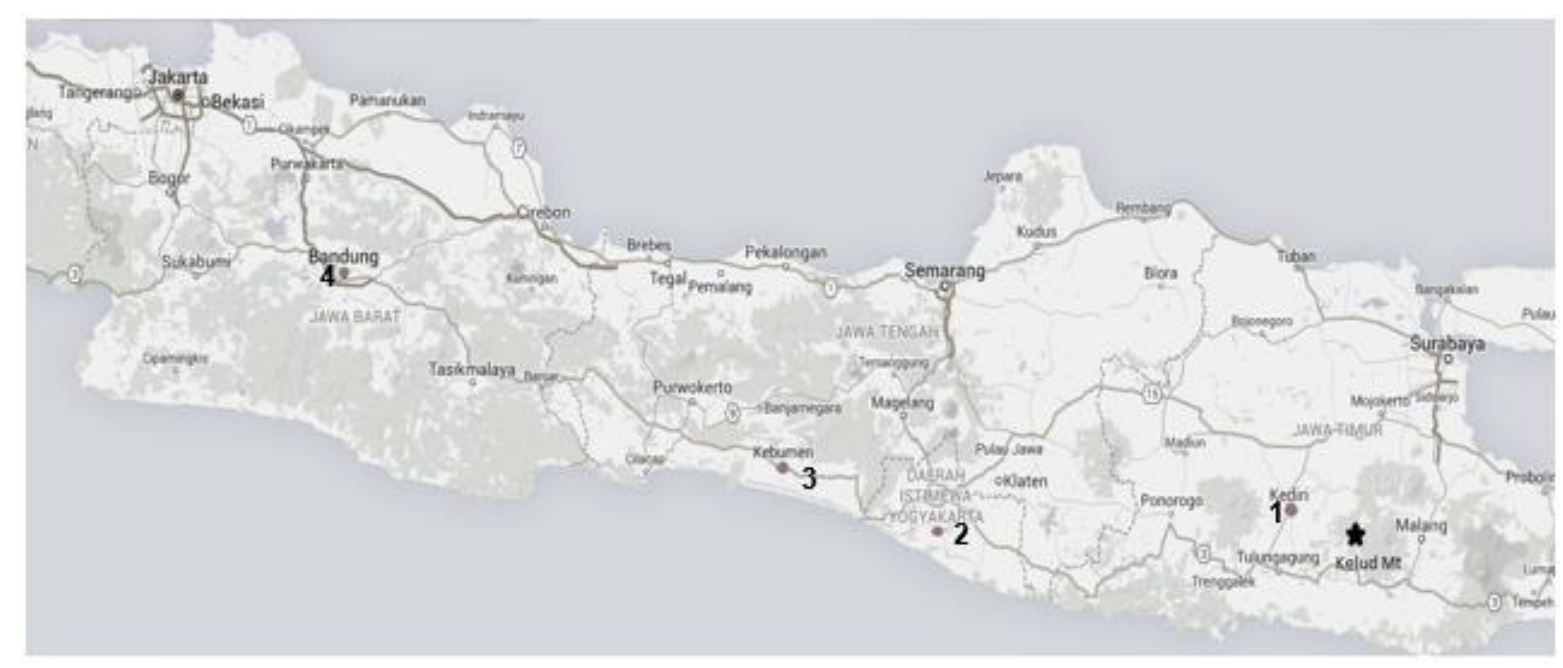

Fig 1. Sampling locations at four sites: 1. Kediri, 2. Yogyakarta, 3. Kebumen, and 4. Bandung in Java Island 
Table 1. Irradiation, decay and counting times

\begin{tabular}{llll}
\hline Elements & Irradiation time & Decay time & Counting time \\
\hline $\mathrm{Al}, \mathrm{Ca}, \mathrm{Ti}, \mathrm{Mn}, \mathrm{Mg}, \mathrm{V}, \mathrm{U}$ & $1 \mathrm{~min}$ & $15 \mathrm{~min}$ & $200 \mathrm{sec}$ \\
$\mathrm{As}, \mathrm{Na}, \mathrm{K}, \mathrm{Sm}, \mathrm{La}$ & $15 \mathrm{~min}$ & $2-3$ days & $30 \mathrm{~min}$ \\
$\mathrm{Ce}, \mathrm{Co}, \mathrm{Cr}, \mathrm{Eu}, \mathrm{Fe}, \mathrm{Hf}, \mathrm{Sc}, \mathrm{Th}, \mathrm{Zn}$ & $120 \mathrm{~min}$ & 2 weeks & $30 \mathrm{~min}$ \\
\hline
\end{tabular}

Table 2. Optimum measurement condition parameters [14]

\begin{tabular}{lccccc}
\hline Elements & Condition & $\begin{array}{c}\text { Voltage } \\
(\mathrm{kV})\end{array}$ & $\begin{array}{c}\text { Current } \\
(\mu \mathrm{A})\end{array}$ & $\begin{array}{c}\text { Filter } \\
\text { material }\end{array}$ & $\begin{array}{c}\text { Measurement } \\
\text { time }(\mathrm{s})\end{array}$ \\
\hline $\mathrm{Mg}, \mathrm{Al}, \mathrm{Ca}, \mathrm{K}, \mathrm{S}, \mathrm{Si}$ & $\mathrm{Na}-\mathrm{Ca}$ & 8 & 700 & none & 300 \\
$\mathrm{As}, \mathrm{Cd}, \mathrm{Cr}, \mathrm{Cu}, \mathrm{Fe}, \mathrm{Mn}, \mathrm{Pb}, \mathrm{Ti}, \mathrm{V}$ and $\mathrm{Zn}$ & $\mathrm{Ti}-\mathrm{Pb}$ & 30 & 110 & $\mathrm{Al}$ & 300 \\
\hline
\end{tabular}

$35 \mathrm{~km}$ in the west, while Yogyakarta, Kebumen and Bandung were 210, 294, and $531 \mathrm{~km}$ away respectively from Kelud volcano. Fieldwork was conducted directly after the volcanic eruption. The thickness of the ash deposit sampled was variable ranging from few centimeters to several decimeters. The materials were sampled on the ground, except for ash collected in Bandung, which was sampled on a building roof. Volcanic ash samples were taken about 500 grams placed in polyethylene bags and transported to the laboratory. They were dried for sun drying in 7 days. The dried samples were homogenized with a mortar and an electrical pulverisette for $60 \mathrm{~min}$, and then sieved using 200 mesh sieves (74 $\mu \mathrm{m}$ sieves). About $25-30 \mathrm{mg}$ of samples were weighed and put into $0.3 \mathrm{~mL}$ polyethylene vials. Standard reference material from National Institute of Standards and Technology (NIST) SRM NIST 2711a Montana soil was used to validate the method. Mix standards for relative method were prepared and placed in the same size vials.

\section{Neutron Activation Analysis Measurement}

The samples, SRMs and standards were irradiated in the rabbit system of The Multi-Purpose Reactor G.A Siwabessy with neutron flux $\sim 10^{13}$ n. $\mathrm{cm}^{-2} . \mathrm{s}^{-1}[15]$. Using different irradiation times allowed us to find a variety of elements present in the samples. After appropriate cooling, samples were counted using HPGe gamma spectrometer with an efficiency of $35 \%$ and FWHM of $2.0 \mathrm{keV}$ at $1.33 \mathrm{MeV}$ from a Co-60 source. Software GENIE 2000 was utilized for spectrum analysis. The irradiation, decay and counting times used were shown in Table 1.

\section{XRF Measurement}

1-2 $\mathrm{g}$ of volcanic ash was put into the sample cup and put into the sample changer for 5-10 min measurement using XRF. XRF spectrometer used was MiniPal4 EDXRF type (PANalytical), equipped with $\mathrm{Rh}$ tube as $\mathrm{x}$-ray generator ( $9 \mathrm{~W} \mathrm{X}$-ray tube, maximum high voltage $30 \mathrm{kV}$, maximum current $1 \mathrm{~mA}$, medium air), 5 tube filters, a high resolution Silicon Drift Detector and a 12-position sample tray with sample spinner. The spinner system provided constant rotation of the samples during the measurements, to reduce errors due to non-homogeneity in the sample preparation [1516]. In order to reduce background, Al filter was used between the source and the sample. To obtain the best possible performance of the spectrometer the following instrumental parameters are able to adapt to each set of the elements: tube-current, voltage, measurement time and path of the x-ray between the sample and detector. A calibration model for qualitative and quantitative analysis was created on the basis of measurements of several standards materials. Quality control was applied by measuring the standard reference material SRM NIST 2711a. The optimum measurement condition parameters of XRF were resumed in Table 2.

\section{RESULT AND DISCUSSION}

\section{Method Validation}

Validation was applied using the standard reference materials SRM NIST 2711a Montana Soil. A comparison of this study results and the NIST value concentrations are given in Table 3. The analysis results showed there were good agreements for most of all elements which the difference with the NIST certificate value were less than $10 \%$. For some trace elements, measurement using NAA showed a better accuracy than XRF due to its sensitivity and the detection limit. Some elements such as $\mathrm{Cu}, \mathrm{Cd}, \mathrm{Pb}$ and Si which cannot be detected well using NAA, were detected using XRF.

\section{Elemental Concentrations in Volcanic Ash}

The concentrations of the elements found in the volcanic ash from four sampling sites are given in Table 4. In this results, NAA method was applied to determine the concentrations of 21 elements Al, As, $\mathrm{Ca}, \mathrm{Ce}, \mathrm{Co}, \mathrm{Cr}$, Eu, Fe, Hf, K, La, Mg, Mn, Na, Sc, Sm, $\mathrm{Th}, \mathrm{Ti}, \mathrm{V}, \mathrm{Zn}$, and $\mathrm{U}$, while XRF was used to determine $\mathrm{Cd}, \mathrm{Cu}, \mathrm{Si}$ and $\mathrm{Pb}$. The values were given in average 
Table 3. Comparison of SRM NIST 2711a analyzed using NAA and XRF to the certificate value

\begin{tabular}{lccc}
\hline Elements & Measured by NAA $(\mathrm{mg} / \mathrm{kg})$ & Measured by XRF $(\mathrm{mg} / \mathrm{kg})$ & NIST value $(\mathrm{mg} / \mathrm{kg})$ \\
\hline $\mathrm{Al}$ & $66374 \pm 1470$ & $64260 \pm 247$ & $67200 \pm 600$ \\
$\mathrm{As}$ & $108 \pm 4$ & $107 \pm 3$ & 107 \\
$\mathrm{Ca}$ & $23203 \pm 1317$ & $23480 \pm 580$ & $24200 \pm 600$ \\
$\mathrm{Cd}$ & $\mathrm{ND}^{*}$ & $51.9 \pm 4.9$ & $54.1 \pm 0.5$ \\
$\mathrm{Ce}$ & $70.01 \pm 5.70$ & $\mathrm{ND}^{*}$ & 70 \\
$\mathrm{Co}$ & $9.89 \pm 0.20$ & $\mathrm{ND}^{*}$ & $9.89 \pm 0.18$ \\
$\mathrm{Cr}$ & $52.72 \pm 1.21$ & $49.73 \pm 1.04$ & $52.3 \pm 2.9$ \\
$\mathrm{Cu}$ & $\mathrm{ND}^{*}$ & $138 \pm 4$ & $140 \pm 2$ \\
$\mathrm{Eu}$ & $1.14 \pm 0.70$ & $\mathrm{ND}^{*}$ & $1.1 \pm 0.2$ \\
$\mathrm{Fe}$ & $28275 \pm 366$ & $28060 \pm 622$ & $28200 \pm 400$ \\
$\mathrm{Hf}$ & $9.2 \pm 0.1$ & $\mathrm{ND}^{*}$ & $9.2 \pm 0.2$ \\
$\mathrm{~K}$ & $22913 \pm 614$ & $26830 \pm 834$ & 25300 \\
$\mathrm{La}$ & $37 \pm 1$ & $\mathrm{ND}^{*}$ & $38 \pm 1$ \\
$\mathrm{Mg}$ & $10701 \pm 1625$ & $10645 \pm 134$ & $10700 \pm 600$ \\
$\mathrm{Mn}$ & $661 \pm 16$ & $656 \pm 11$ & $675 \pm 18$ \\
$\mathrm{Na}$ & $12186 \pm 30$ & $\mathrm{ND}^{*}$ & 12000 \\
$\mathrm{~Pb}$ & $\mathrm{ND}$ & $1394 \pm 9.7$ & $1400 \pm 10$ \\
$\mathrm{Sc}$ & $8.4 \pm 0.1$ & $\mathrm{ND}^{*}$ & $8.5 \pm 0.1$ \\
$\mathrm{Si}$ & $\mathrm{ND}$ & $316500 \pm 8942$ & $314000 \pm 7000$ \\
$\mathrm{Sm}$ & $5.83 \pm 0.22$ & $\mathrm{ND}^{*}$ & $5.93 \pm 0.28$ \\
$\mathrm{Th}$ & $15 \pm 1$ & $\mathrm{ND}^{*}$ & $15 \pm 1$ \\
$\mathrm{Ti}$ & $3159 \pm 375$ & $3250 \pm 127$ & $3170 \pm 80$ \\
$\mathrm{U}$ & $3.02 \pm 1.12$ & $\mathrm{ND}^{*}$ & $3.01 \pm 0.12$ \\
$\mathrm{~V}$ & $76.6 \pm 5.7$ & $91.6 \pm 3.7$ & $80.7 \pm 5.7$ \\
$\mathrm{Zn}$ & $424 \pm 10$ & $413 \pm 15$ & $414 \pm 11$ \\
$\mathrm{ND}$ & & &
\end{tabular}

Table 4. Concentrations of elements of volcanic ash from four sampling sites

\begin{tabular}{lccccc}
\hline Elements & Unit & Kediri & Yogyakarta & Kebumen & Bandung \\
\hline $\mathrm{Al}$ & $\%$ & $12.13 \pm 0.26$ & $8.15 \pm 0.28$ & $10.33 \pm 0.26$ & $10.25 \pm 0.46$ \\
$\mathrm{Ca}$ & $\%$ & $5.85 \pm 0.61$ & $4.22 \pm 0.47$ & $4.70 \pm 0.55$ & $4.63 \pm 0.59$ \\
$\mathrm{Fe}$ & $\%$ & $4.09 \pm 0.14$ & $4.92 \pm 0.16$ & $5.77 \pm 0.17$ & $4.99 \pm 0.17$ \\
$\mathrm{~K}$ & $\%$ & $0.43 \pm 0.07$ & $0.80 \pm 0.08$ & $0.79 \pm 0.07$ & $0.60 \pm 0.09$ \\
$\mathrm{Mg}$ & $\%$ & $1.70 \pm 0.38$ & $1.35 \pm 0.33$ & $1.34 \pm 0.31$ & $1.66 \pm 0.43$ \\
$\mathrm{Mn}$ & $\%$ & $0.11 \pm 0.01$ & $0.11 \pm 0.01$ & $0.13 \pm 0.01$ & $0.11 \pm 0.01$ \\
$\mathrm{Na}$ & $\%$ & $1.53 \pm 0.01$ & $2.20 \pm 0.01$ & $1.78 \pm 0.01$ & $1.86 \pm 0.01$ \\
$\mathrm{Si}{ }^{*}$ & $\%$ & $27.9 \pm 0.74$ & $27.0 \pm 0.72$ & $27.1 \pm 0.73$ & $24.6 \pm 0.66$ \\
$\mathrm{Ti}$ & $\%$ & $0.32 \pm 0.08$ & $0.57 \pm 0.11$ & $0.43 \pm 0.10$ & $0.43 \pm 0.08$ \\
$\mathrm{As}$ & $\mathrm{mg} / \mathrm{kg}$ & $3.23 \pm 1.36$ & $4.42 \pm 1.36$ & $3.28 \pm 1.51$ & $3.38 \pm 1.48$ \\
$\mathrm{Cd}$ & $\mathrm{mg} / \mathrm{kg}$ & $17.63 \pm 1.80$ & $20.49 \pm 2.10$ & $24.04 \pm 2.30$ & $20.94 \pm 2.10$ \\
$\mathrm{Ce}$ & $\mathrm{mg} / \mathrm{kg}$ & $9.84 \pm 1.40$ & $18.43 \pm 1.59$ & $14.52 \pm 1.62$ & $16.27 \pm 1.58$ \\
$\mathrm{Co}$ & $\mathrm{mg} / \mathrm{kg}$ & $12.67 \pm 0.70$ & $10.86 \pm 0.72$ & $16.03 \pm 0.83$ & $14.09 \pm 0.76$ \\
$\mathrm{Cr}$ & $\mathrm{mg} / \mathrm{kg}$ & $12.74 \pm 2.16$ & $11.19 \pm 2.36$ & $15.72 \pm 2.34$ & $17.79 \pm 2.21$ \\
$\mathrm{Cu}$ & $\mathrm{mg} / \mathrm{kg}$ & $49.26 \pm 1.68$ & $76.96 \pm 2.62$ & $77.10 \pm 2.63$ & $63.27 \pm 2.16$ \\
$\mathrm{Eu}$ & $\mathrm{mg} / \mathrm{kg}$ & $0.73 \pm 0.10$ & $1.02 \pm 0.12$ & $0.95 \pm 0.12$ & $0.90 \pm 0.12$ \\
$\mathrm{Hf}$ & $\mathrm{mg} / \mathrm{kg}$ & $1.09 \pm 0.22$ & $2.26 \pm 0.26$ & $1.94 \pm 0.25$ & $1.93 \pm 0.27$ \\
$\mathrm{La}$ & $\mathrm{mg} / \mathrm{kg}$ & $2.25 \pm 0.63$ & $5.66 \pm 1.55$ & $3.12 \pm 0.80$ & $5.18 \pm 1.56$ \\
$\mathrm{~Pb}{ }^{*}$ & $\mathrm{mg} / \mathrm{kg}$ & $35.2 \pm 0.50$ & $31.4 \pm 0.44$ & $41.9 \pm 0.58$ & $42.7 \pm 0.60$ \\
$\mathrm{Sc}$ & $\mathrm{mg} / \mathrm{kg}$ & $13.73 \pm 0.16$ & $14.27 \pm 0.16$ & $15.76 \pm 0.18$ & $15.38 \pm 0.18$ \\
$\mathrm{Sm}$ & $\mathrm{mg} / \mathrm{kg}$ & $1.34 \pm 0.14$ & $2.22 \pm 0.16$ & $2.63 \pm 0.15$ & $1.76 \pm 0.17$ \\
$\mathrm{Th}$ & $\mathrm{mg} / \mathrm{kg}$ & $1.21 \pm 0.16$ & $1.52 \pm 0.18$ & $1.42 \pm 0.18$ & $1.81 \pm 0.18$ \\
$\mathrm{U}$ & $\mathrm{mg} / \mathrm{kg}$ & $4.7 \pm 1.8$ & $3.8 \pm 1.8$ & $3.0 \pm 1.7$ & $4.4 \pm 1.6$ \\
$\mathrm{~V}$ & $\mathrm{mg} / \mathrm{kg}$ & $135.9 \pm 11.5$ & $136.5 \pm 12.7$ & $203.8 \pm 12.4$ & $120.5 \pm 8.4$ \\
$\mathrm{Zn}$ & $\mathrm{mg} / \mathrm{kg}$ & $44.35 \pm 14.09$ & $84.98 \pm 10.46$ & $77.93 \pm 18.07$ & $300.2 \pm 23.1$ \\
\hline${ }^{*} \mathrm{determined} \mathrm{using} \mathrm{XRF}$ & & & &
\end{tabular}

from triplicate samples. The results between four sampling sites showed that relative standard deviation was less than 25-30\% and did not differ for most elements, except for $\mathrm{Zn}$. The concentration of $\mathrm{Zn}$ was 
higher in Bandung sites, which 4-7 times higher than others. This could be happened due to that Bandung ash sample was taken from the metal building roof. This high concentration was assumed contaminated from the $\mathrm{Zn}$ roof. Metal surfaces on the roofs can cause extreme pollution with heavy metals $\mathrm{Zn}$ that content in the roof [17]. The similarity of elements concentrations in volcanic ashes collected from four different sites showed that the volcanic ashes have dispersed and reached more than $500 \mathrm{~km}$ from the source, and they have similar composition, which showed there were no distance effects in the composition. Daga et al. have studied that the samples collected in sites located at 100 and $220 \mathrm{~km}$ from the volcano with a 6-day time interval, corresponding to different eruptive phases, have similar grain size and particle characteristics and also similar composition. In the distance less than $220 \mathrm{~km}$, it showed that the morphology and composition have no effect on distance [18]. While Ruggieri et al. studied fine particles up to $530 \mathrm{~km}$ from the volcano that the material decreased the grain size with the distance [19].

The major elements consist of crustal elements such as $\mathrm{Al}, \mathrm{Ca}, \mathrm{Fe}, \mathrm{K}, \mathrm{Mg}, \mathrm{Mn}, \mathrm{Na}, \mathrm{Si}$, and $\mathrm{Ti}$. The samples have high concentrations of Al (8.15-12.03 $\% w t), \mathrm{Ca}(4.22-5.85 \% \mathrm{wt})$, and Fe (4.09-5.77\%wt), but relatively low contents of $\mathrm{K}(0.43-0.80 \% \mathrm{wt}), \mathrm{Na}$ (mean < $1.84 \% \mathrm{wt}$ ), $\mathrm{Mn}$ (mean < $0.12 \% \mathrm{wt}$ ), and $\mathrm{Ti}$ (mean $<0.44$ $\% \mathrm{wt})$. The $\mathrm{Si}$ contents showed little variation ( 26.7 $\% w t)$, with this $\mathrm{SiO}_{2}$ percentage $\left(\mathrm{SiO}_{2}\right.$ in bulk samples of ash is expected to be around 53-60\%) the Kelud eruptions are basaltic andesite [20].

The morphology of ash eruptions of high viscosity magma (rhyolitic, dacitic, and some andesitic magma) is entirely dependent on the shape of vesicles in the rising magma before disintegration [20]. Kelud volcanic eruption magma is more likely basaltic andesite which has a lower content of silica. With the content of potassium, they are medium- $K$ basaltic andesite [21-22]. It should be noted that silica in the Kelud volcanic ash was not the free crystalline silica but mixed with other oxides such as $\mathrm{Fe}, \mathrm{Al}, \mathrm{K}$ and other elements. However, volcanic ashes containing less than $58 \% \mathrm{SiO}_{2}$ are thought to be unlikely to contain crystalline silica [6]. The presence of crystalline silica has the potential to cause silicosis (a chronic lung disease resulting in scarring damage to the lungs and impairment of their function) [6].

\section{Toxic Elements and Environmental Implications}

Explosive volcanic eruption could impact the surrounding environment and further distance in different time and spatial scale [23], as it contains several amount of toxic elements and elemental pollutants. From Kelud eruption, the volcanic ash contains toxic elements As,
$\mathrm{Cd}, \mathrm{Cu}, \mathrm{Co}, \mathrm{Cr}$, and $\mathrm{Pb}$ which range 3.23-4.42, 17.63$24.09,49.26-77.10,10.86-16.03,11.19-17.79$, and $31.4-42.7 \mathrm{mg} / \mathrm{kg}$, respectively. The values for Cu were lower than in volcanic ashes from Copahue, Lonquimay, Llaima and Hudson in Chile and Argentina which varied from 41.05 to $108.70 \mathrm{mg} / \mathrm{kg}$ [24]. The level concentrations of $\mathrm{As}$, Co and $\mathrm{Cr}$ from Kelud volcanic ashes were at the same level to the Sinabung volcanic ash with average value were $4.48,17.1$, and $11.8 \mathrm{mg} / \mathrm{kg}$, respectively [5]. The concentration of As and Co were also similar with Merapi volcanic ash (3.44 and $16.0 \mathrm{mg} / \mathrm{kg}$, respectively) [8]. These heavy metals are in similar concentrations for natural levels of heavy metals in soil [25]. Even though these heavy metals are in safety level of concentration, but particular attention should be given to semi volatile as, which is potential toxic for the environmental and can be associated considering its affinity of gas phase or forming volatile compounds at magmatic temperatures and being absorbed onto ash particles [23]. Arsenic was found between the most mobile elements in Chaiten volcano 2008 ashes which release a high amount of arsenic to the environment in the first ash and water interaction [26]. Further bulk ash leachate analysis is needed to ensure the release of certain toxic elements into aqueous environments.

\section{Geochemical Information}

The geochemical information obtained from volcanic ash samples from direct fallout with clear dispersion source correlation, allows a precise characterization of the tephra provenance. Rare earth elements (REE) such as $\mathrm{Ce}, \mathrm{Eu}, \mathrm{La}$, and $\mathrm{Sm}$ were $9.84-18.43, \quad 0.73-1.02, \quad 2.25-5.66$, and 1.34-2.63 $\mathrm{mg} / \mathrm{kg}$, respectively. Rare earth elements are often considered in isolation from the other trace elements [23]. It is conventional to normalize concentrations against a chondritic source, with the values of Boynton (1984) being used in this study [27]. The fractionation degree of a REE pattern can be expressed by the ratio of the concentration of a light REE ( $\mathrm{La}$ or $\mathrm{Ce}$ ) to middle REE (Eu or Sm), normalized by Chondrite of Boynton's value [23]. The ratio of $\mathrm{LaN}_{\mathrm{N}}$ to $S \mathrm{~m}_{\mathrm{N}}$ (chondrite normalized) was $1.06-1.85$ which is relatively similar to the value reported by Daga et al. for Volcano Calbuco 1961, Cordon Caulle Volcanic Complex 1960 and 2011 event [23].

Concentrations of $\mathrm{Hf}$, Th and $\mathrm{U}$ were 1.09-2.26, $1.21-1.81$ and $3.03-4.70 \mathrm{mg} / \mathrm{kg}$, respectively. Basic or ultrabasic rocks such as basalt and komatiite are generally thought to have low Th and U contents (Th < $3 \mathrm{ppm}$ and $U<2 \mathrm{ppm}$ ), and post-Archean granite, felsic volcanic rock, and intermediate andesite have high content of Th and $U$ (Th >3 ppm and $U>2$ ppm) [23]. In 
this study, the ashes have relatively high concentrations of $U$ but low content of Th. Volcanic ashes from many different volcanoes contain less than $1 \mathrm{ppm}$ up to 11 ppm of uranium $[5,8,24]$. In most cases, thorium is also present. The amount of radioactive materials given off by volcanoes is small, and it varies greatly with the location of the volcano and with the stage of eruption

\section{CONCLUSION}

We have utilized the nuclear analytical methods neutron activation analysis and $\mathrm{X}$-ray fluorescence to identify several elements including rare earth elements in Kelud volcanic ash with good accuracy and high precision. The analysis results of volcanic ashes showed a wide range of elements, major elements $\mathrm{Al}, \mathrm{Ca}, \mathrm{Fe}, \mathrm{K}$, $\mathrm{Mg}, \mathrm{Mn}, \mathrm{Na}, \mathrm{Si}$ and $\mathrm{Ti}$, trace elements $\mathrm{As}, \mathrm{Cd}, \mathrm{Cu}, \mathrm{Co}$, $\mathrm{Cr}, \mathrm{V}, \mathrm{Zn}, \mathrm{Hf}$, Th, and U, rare earth elements $\mathrm{Ce}$, Eu, La and $\mathrm{Sm}$ and heavy metals $\mathrm{As}, \mathrm{Cd}, \mathrm{Cu}, \mathrm{Co}, \mathrm{Cr}$, and $\mathrm{Pb}$ were identified. Kelud volcanic eruption magma is more likely basaltic andesite which have a lower content of silica, and with the content of potassium, they are medium- $K$ basaltic andesite. Kelud volcanic ash containing less than $58 \% \mathrm{SiO}_{2}$ is unlikely to contain crystalline silica, which has no potential harm to cause silicosis or chronic lung disease. The results of heavy metals As, $\mathrm{Cd}, \mathrm{Cu}, \mathrm{Co}, \mathrm{Cr}$, and $\mathrm{Pb}$ are in the similar natural levels of concentrations in soil, and should not have toxic on plants or human health. The characteristic of trace elements in volcanic ashes collected from four different sites also showed that the volcanic ashes have dispersed and reached more than $500 \mathrm{~km}$ from the source, and they have similar composition, which showed there were no distance effects in the composition. The publications related trace elements in volcanic ash especially Indonesian volcano are scarce and limited. This study appears to be informative to contribute for the Indonesia volcanic ash data.

\section{ACKNOWLEDGEMENT}

The authors would like to express appreciation to research members in Nuclear Analytical Techniques group in Center of Applied Nuclear Science and Technology, operator and technician of Reactor G.A Siwabessy in Serpong, Indonesia for providing support in irradiation, and National Nuclear Energy Agency for their financial support of this project 2015 fiscal year budget.

\section{REFERENCES}

[1] Kelud Volcano, http://www.ulb.ac.be/sciences/cvl/ DKIPART2.pdf, accessed on April 2015.
[2] Kristiansen, N.I., Prata, A.J., Stohl, A., and Carn, S.A., 2015, Stratospheric volcanic ash emissions from the 13 February 2014 Kelut eruption, Geophys. Res. Lett., 42 (2), 588-596.

[3] Global Volcanism Program, 2014, "Report on Kelut (Indonesia)", in Bulletin of the Global Volcanism Network, Wunderman, R., (ed.), Smithsonian Institution, Washington, D.C., 39 (2), 8-21.

[4] Ruggieri, F., Fernandez-Turiel, J.L., Saavedra, J., Gimeno, D., Polanco, E., Amigo, A., Galindo, G., and Caselli, A., 2012, Contribution of volcanic ashes to the regional geochemical balance: The 2008 eruption of Chaitén volcano, Southern Chile, Sci. Total Environ., 425, 75-88.

[5] Kusmartini, I., Syahfitri, W.Y.N., Kurniawati, S., Lestiani, D.D., and Santoso, M., 2017, Elemental characterization of Mt. Sinabung volcanic ash, Indonesia by neutron activation analysis, J. Phys. Conf. Ser., 860 (1), 12005.

[6] Horwell, C.J., and Baxter, P.J., 2006, The respiratory health hazards of volcanic ash: A review for volcanic health risk mitigation, Bull. Volcanol., 69 (1), 1-24.

[7] Fiantis, D., Nelson, M., Shamshuddin, J., Goh, T.B., and Van Ranst, E., 2011, Changes in the chemical and mineralogical properties of Mt. Talang volcanic ash in West Sumatra during the initial weathering phase, Commun. Soil Sci. Plant Anal., 42 (5), 569-585.

[8] Canion, B., Jacques, C., Landsberger. S., and Taftazani, A., 2012, Trace analysis of Indonesian volcanic ash using thermal and epithermal neutron activation analysis, Nukleonika, 57 (4), 585-589.

[9] Bourdier, J.L., Pratomo, I., Thouret, J.C., Boudon, G., and Vincent, P.M., 1997, Observation, stratigraphy, and eruptive processes of the 1990 eruption of Kelut volcano Indonesia, J. Volcanol. Geotherm. Res., 79 (3-4), 181-203.

[10] Greenberg, R.R., 2008, Pushing the limits of NAA: Accuracy, uncertainty and detection limits, J. Radioanal. Nucl. Chem., 278 (2), 231-240.

[11] Glascock, M.D., 2004, Overview of Neutron Activation Analysis, University of Missouri Research Reactor (MURR). Columbia, MO. http://archaeometry.missouri.edu/naa_overview.ht $\mathrm{ml}$, accessed on 7 Nov 2008.

[12] Watson, J.G., Chow, J.C., and Frazier, C.A., 1999, "X-ray Fluorescence Analysis of Ambient Air Analysis, in Handbook of Elemental Analysis of Airborne Particles, Landsberger, S., (ed.), Gordon and Breach Science Publisher, Amsterdam.

[13] Brouwer, P., 2006, Theory of XRF, $2^{\text {nd }}$ ed., PANalytical BV, Almelo, Amsterdam.

[14] Syukria, K., Indah, K., Natalia, A., and Diah, D.L., 2012, Applicability of ED-XRF spectrometer for 
sediment analysis, Proceeding of Nuclear Analytical Technique, 152-158.

[15] Lestiani, D.D., Muhayatun, M., and Adventini, N., 2009, Application of neutron activation analysis in characterization of environmental SRM samples, Indones. J. Chem., 9 (2), 231-235.

[16] Oreščanin, V., Mikelić, I.L., Mikelić, L., and Lulić, S., 2008, Applicability of minipal 4 compact EDXRF spectrometer for soil and sediment analysis. $X$-Ray Spectrom., 37 (5), 508-511.

[17] Förster, J., 1996, Patterns of roof runoff contamination and their potential implications on practice and regulation of treatment and local infiltration, Water Sci. Technol., 33 (6),39-48.

[18] Liao, Z., Hu, W., Cao, J., Wang, X., Yao, S., Wu, H., and Wan, Y., 2016, Heterogeneous volcanism across the Permian-Triassic Boundary in South China and implications for the Latest Permian Mass Extinction: New evidence from volcanic ash layers in the Lower Yangtze Region, J. Asian Earth Sci., 127, 197-210.

[19] Ruggieri, F., Fernandez-Turiel, J.L., Saavedra, J., Gimeno, D., Valenzuela, E.P., and Naranjo, J.A., 2011, Environmental geochemistry of recent volcanic ashes from Southern Andes, Environ. Chem., 8 (3), 236-247.

[20] Nakagawa, M., and Ohba, T., 2003, Minerals in volcanic ash 1: Primary minerals and volcanic glass, Global Environ. Res., 6 (2), 41-51.
[21] Rahman, M., Sunaryo, S., and Susilo, A., 2014, Pendugaan struktur bawah permukaan 21/2 dimensi di kawasan gunung api Kelud berdasarkan survei gravitasi, Natural B, 2 (3), 221-228.

[22] Characteristics of magma. http://www.tulane.edu/ sanelson/Natural_Disasters/volcan\&magma.htm, accessed on 5 Sept 2015.

[23] Daga, R., Guevara, S.R., Poire, D.G., and Arribére, M., 2014, Characterization of tephras dispersed by the recent eruptions of volcanoes Calbuco (1961), Chaitén (2008) and Cordón Caulle Complex (1961 and 2011), in Northern Patagonia, J. South Am. Earth Sci., 49, 1-14.

[24] Ruggieri, F., Saavedra, J., Fernandes-Turiel, J.L., Gimeno, D., and Garcia-Valles, M., 2010, Environmental geochemistry of ancient volcanic ashes, J. Hazard. Mater., 183 (1-3), 353-365.

[25] Tchounwou, P.B., Yedjou, C.G., Patlolla, A.K., and Sutton, D.J., 2012, Heavy metals toxicity and the environment, EXS, 101, 133-164.

[26] Ruggieri, F., Fernandez-Turiel, J., Saavedra, J., Gimeno, D., Valenzuela, E.P., Amigo, A., Galindo, G., and Caselli, A.T., 2012, Contribution of volcanic ashes to the regional geochemical balance: The 2008 eruption of Chaitén volcano, Southern Chile, Sci. Total Environ., 425, 75-88.

[27] Boynton, W.V., 1984, Chapter 3: Cosmochemistry of the rare earth elements: Meteorite studies, Dev. Geochem., 2, 63-114. 